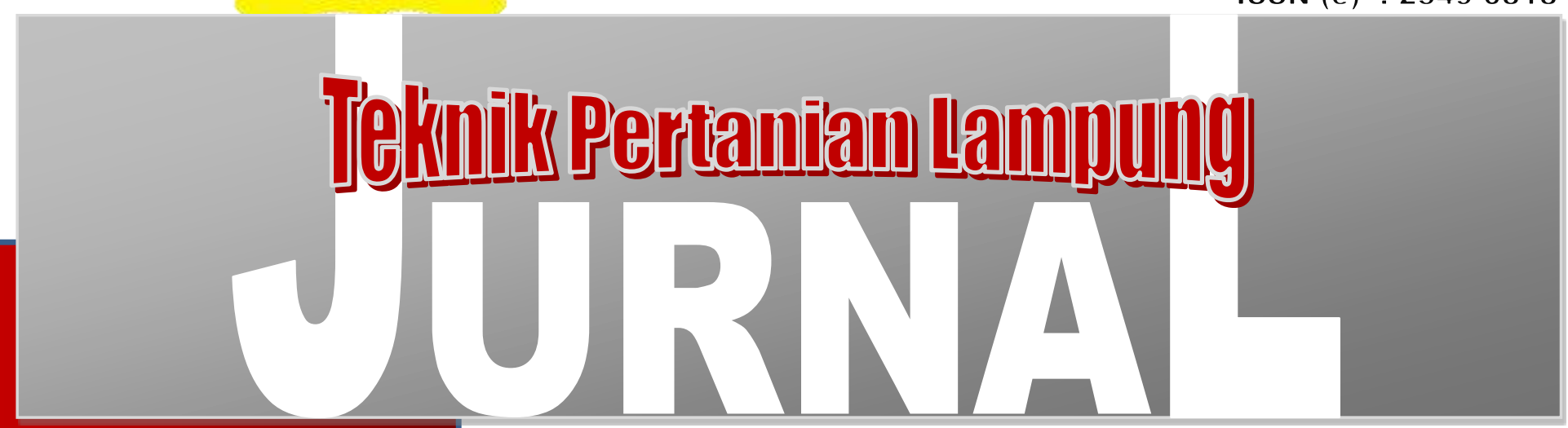

Vol. 7, No. 2, Agustus 2018 


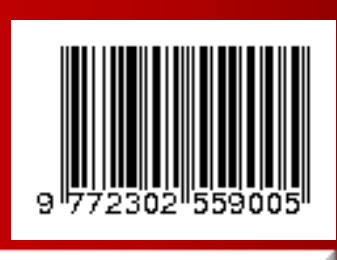


ISSN (p): 2302-559X

ISSN (e): 2549-0818

\section{Geanal TEKNIK PERTANIAN LAMPUNG}

\section{Vol. 7 No. 2, Agustus 2018}

Jurnal Teknik Pertanian (J-TEP) merupakan publikasi ilmiah yang memuat hasil-hasil penelitian, pengembangan, kajian atau gagasan dalam bidang keteknikan pertanian. Lingkup penulisan karya ilmiah dalam jurnal ini antara lain: rekayasa sumber daya air dan lahan, bangunan dan lingkungan pertanian, rekayasa bioproses dan penanganan pasca panen, daya dan alat mesin pertanian, energy terbarukan, dan system kendali dan kecerdasan buatan dalam bidang pertanian. J-TEP terbit sebanyak 3 (tiga) kali dalam satu tahun. Mulai tahun 2018 J-TEP menerbitkan jurnla pada bulan April, Agustus, dan Desember. J-TEP terbuka untuk umum, peneliti, mahasiswa, praktisi, dan pemerhati dalam dunia keteknikan pertanian.

\section{Ketua Editor}

Dr. Ir. Agus Haryanto, M.P

\section{Reviewer}

Prof. Dr. Ir, R.A. Bustomi Rosadi, M.S. (Manajemen Irigasi, Universitas Lampung)

Prof. Dr. Ir. Udin Hasanudin, M.T (Pengelolaan Limbah Agroindustri, Universitas Lampung)

Ir. Mimin Muhaemin, M.Eng., Ph.D (Mekanisasi Pertanian, Universitas Padjajaran)

Dr. Ir. Sugeng Triyono, M.Sc. (Rekayasa Sumberdaya Lahan dan Air, Universitas Lampung)

Dr. Eng Muhammad Makky (Teknik Biosistem, Universitas Andalas)

Dr. Diding Suhandy, S.TP., M.Agr (Spektroskopi, Universitas Lampung)

Dr. Ir. Wiludjeng Trisasiwi, MP (Energi Terbarukan, Universitas Jenderal Soedirman)

Dr. Sri Rahayoe, S.TP, M.P (Pengolahan Pangan, Universitas Gadjah Mada)

\section{Dewan Redaksi}

Ketua : Ahmad Tusi, S.TP, M.Si

Sekretaris : Cicih Sugianti, S.TP, M.Si

Anggota : Dr. Mareli Telaumbanuwa, S.TP, M.Sc

Winda Rahmawati, S.TP, M.Si., M.Sc

Tri Wahyu Saputra, S.T.P. M.Sc.

Jurnal Teknik Pertanian diterbitkan oleh Jurusan Teknik Pertanian, Universitas Lampung.

\section{Alamat Redaksi J-TEP:}

Jurusan Teknik Pertanian, Fakultas Pertanian

Universitas Lampung

Jl. Soemantri Brodjonegoro No.1

Telp. 0721-701609 ext. 846

Website :http://jurnal.fp.unila.ac.id/index.php/JTP

Email :jurnal tep@fp.unila.ac.id dan ae.journal@yahoo.com 


\section{PENGANTAR REDAKSI}

Dengan mengucapkan puji syukur kepada Allah yang Maha Kuasa, Jurnal Teknik Pertanian (JTEP) Volume 7 No 2 Tahun 2018 dapat diterbitkan. Pada edisi kali ini dimuat 7 (tujuh) artikel yang merupakan karya tulis ilmiah dari berbagai bidang kajian dalam dunia Keteknikan Pertanian yang meliputi modifikasi mesin peniris minyak dan analisis kelayakan produksi keripik bayam, kajian media tanam hidroponik dengan media baglog dan arang sekam, penentuan parameter kinetika pada sintesis biodeisel, evaluasi non-destrustif asam lemak bebas dengan spektroskopi, uji kinerja alat pengering jagung, unjuk kerja mesin pemotong padi, dan evaluasi mutu biji melinjo dengan citra digital.

Pada kesempatan kali ini kami menyampaikan ucapan terima kasih yang sebesar-besarnya kepada para penulis atas kontribusinya dalam Jurnal TEP dan kepada para reviewer/penelaah jurnal ini atas peran sertanya dalam meningkatkan mutu karya tulis ilmiah yang diterbitkan dalam edisi ini.

Akhir kata, semoga Jurnal TEP ini dapat bermanfaat bagi masyarakat dan memberikan konstribusi yang berarti bagi pengembangan ilmu pengetahuan dan teknologi, khususnya di bidang keteknikan pertanian.

\section{Redaksi J TEP-Lampung}

ISSN (p): 2302-559X

ISSN (e): 2549-0818 


\section{Gencual TEKNIK PERTANIAN LAMPUNG}

Vol. 7 No. 2, Agustus 2018

Halaman

Daftar isi

Pengantar Redaksi

MODIFIKASI MESIN PENIRIS MINYAK DAN KELAYAKAN FINANSIAL PRODUKSI

KERIPIK BAYAM

Ahmad Thoriq, Totok Herwanto, Drupadi Ciptaningtyas

PENENTUAN NILAI PARAMETER KINETIKA ORDE SATU PADA SINTESIS BIODIESEL DARI MINYAK JELANTAH

Amieria Citra Gita, Agus Haryanto, Tri Wahyu Saputra, Mareli Telaumbanua

EVALUASI NON-DESTRUKTIF KANDUNGAN ASAM LEMAK BEBAS (ALB)

80-87

TANDAN BUAH SEGAR (TBS) KELAPA SAWIT DENGAN METODE NIR

SPEKTROSKOPI

Zaqlul Iqbal, Sam Herodian, Slamet Widodo

UJI KINERJA ALAT PENGERING SILINDER VERTIKAL PADA PROSES

$88-96$

PENGERINGAN JAGUNG (Zea mays ssp.mays)

Made Aditya Putra, Sandi Asmara, Cicih Sugianti, Tamrin

UNJUK KERJA MESIN PEMOTONG PADI (PADDY MOWER) SAAT PEMANENAN

PADI (Oryza Sativa L.) DI LAHAN BASAH

Siti Anisa, Siti Suharyatun, Oktafri, Sandi Asmara

EVALUASI MUTU BIJI MELINJO (Gnetum gnemon L.) MENGGUNAKAN

PENGOLAHAN CITRA DIGITAL

Slamet Widodo dan Muhammad Kalili

KAJIAN MEDIA TANAM HIDROPONIK DARI CAMPURAN BAHAN BAKU LIMBAH BAGLOG DAN ARANG SEKAM

Dyah Isworo, Sugeng Triyono, Agus Haryanto, Iskandar Zulkarnain 


\section{PEDOMAN PENULISAN ARTIKEL BAGI PENULIS}

1) Naskah: Redaksi menerima sumbangan naskah/tulisan ilmiah dalam bahasa Indonesia atau bahasa Inggris, dengan batasan sebagai berikut :

a. Naskah diketik pada kertas ukuran A4 $(210 \mathrm{~mm}$ x $297 \mathrm{~mm})$ dengan 2 spasi dan ukuran huruf Times New Roman 12pt. Jarak tepi kiri, kanan, atas, dan bawah masing-masing $3 \mathrm{~cm}$. Panjang naskah tidak melebihi 20 halaman termasuk abstrak, daftar pustaka, tabel dan gambar. Semua tabel dan gambar ditempatkan terpisah pada bagian akhir naskah (tidak disisipkan dalam naskah) dengan penomoran sesuai dengan yang tertera dalam naskah. Naskah disusun dengan urutan sebagai berikut: Judul; Nama Penulis disertai dengan catatan kaki tentang instansi tempat bekerja; Pendahuluan; Bahan dan Metode; Hasil dan Pembahasan; Kesimpulan dan Saran; Daftar Pustaka; serta Lampiran jika diperlukan. Template penulisan dapat didownload di http://jurnal.fp.unila.ac.id/index.php/JTP

b. Abstrak (Abstract) dalam bahasa Indonesia dan bahasa Inggris, tidak lebih dari 200 kata. Mengandung informasi yang tertuang dalam penulisan dan mudah untuk dipahami. Ringkasan (abstract) harus memuat secara singkat latar belakang, tujuan, metode, serta kesimpulan dan yang merupakan high light hasil penelitian.

c. Pendahuluan: memuat latar belakang masalah yang mendorong dilaksanakannya perekayasaan dan penelitian, sitasi dari temuan-temuan terdahulu yang berkaitan dan relevan, serta tujuan perekayasaan atau penelitian.

d. Bahan dan Metoda: secara jelas menerangkan bahan dan metodologi yang digunakan dalam perekayasaan atau penelitian berikut dengan lokasi dan waktu pelaksanaan, serta analisis statistik yang digunakan. Rujukan diberikan kepada metoda yang spesifik.

e. Hasil dan Pembahasan: Memuat hasil-hasil perekayasaan atau penelitian yang diperoleh dan kaitannya dengan bagaimana hasil tersebut dapat memecahkan masalah serta implikasinya. Persamaan dan perbedaannya dengan hasil perekayasaan atau penelitian terdahulu serta prospek pengembangannya. Hasil dapat disajikan dengan menampilkan gambar, grafik, ataupun tabel.

f. Kesimpulan dan Saran: memuat hal-hal penting dari hasil penelitian dan kontribusinya untuk mengatasi masalah serta saran yang diperlukan untuk arah perekayasaan dan penelitian lebih lanjut.

g. Daftar Pustaka: disusun secara alfabetis menurut penulis, dengan susunan dan format sebagai berikut: Nama penulis didahului nama family/nama terakhir diikuti huruf pertama nama kecil atau nama pertama. Untuk penulis kedua dan seterusnya ditulis kebalikannya. Contoh:

- Kepustakaan dari Jurnal:

Tusi, Ahmad, dan R.A. Bustomi Rosadi. 2009. Aplikasi Irigasi Defisit pada Tanaman Jagung. Jurnal Irigasi. 4(2): 120-130.

- Kepustakaan dari Buku:

Keller, J., and R.D. Bleisner. 1990. Sprinkle and Trickle Irrigation. AVI Publishing Company Inc. New York, USA.

h. Satuan: Satuan harus menggunakan system internasional (SI), contoh : $\mathrm{m}$ (meter), $\mathrm{N}$ (newton), ${ }^{\circ} \mathrm{C}$ (temperature), kW dan W (daya), dll.

2) PenyampaianNaskah:Naskah/karya ilmiah dapat dikirimkan ke alamatdalambentuksoft copyke :

Redaksi J-TEP(JurnalTeknikPertanianUnila)

Jurusan Teknik Pertanian, Fakultas Pertanian

Universitas Lampung

Jl. Sumantri Brodjonegoro No. 1

Telp. 0721-701609 ext. 846

Website : http://jurnal.fp.unila.ac.id/index.php/JTP

Email : jurnal.tep@fp.unila.ac.id atau ae.journal@yahoo.com

3) Selama proses penerimaan karya ilmiah, penelaahan oleh Reviewer, sampai diterimanya makalah untuk diterbitkan dalam jurnal akan dikonfirmasi kepada penulis melalui email.

4) Reviewer berhak melakukan penilaian, koreksi, menambah atau mengurangi isi naskah/tulisan bila dianggap perlu, tanpa mengurangi maksud dan tujuan penulisan. 


\title{
PENENTUAN NILAI PARAMETER KINETIKA ORDE SATU PADA SINTESIS BIODIESEL DARI MINYAK JELANTAH
}

\section{DETERMINING PARAMETERS OF FIRST ORDER KINETICS ON BIODIESEL SYNTHESIS FROM WASTE COOKING OIL}

\author{
Amieria Citra Gita $^{1 *}$, Agus Haryanto ${ }^{1}$, Tri Wahyu Saputra ${ }^{1}$, Mareli Telaumbanua ${ }^{1}$ \\ ${ }^{1}$ Jurusan Teknik Pertanian Fakultas Pertanian Universitas Lampung \\ *komunikasi penulis, email: citraamieria@gmail.com \\ DOI:http://dx.doi.org/10.23960/jtep-l.v7.i2.72-79 \\ Naskah ini diterima pada 26 Februari 2018; revisi pada 16 Agustus 2018; \\ disetujui untuk dipublikasikan pada 16 Agustus 2018
}

\begin{abstract}
Biodiesel is one of alternative energy of diesel engine or diesel fuel from transesterification method by reacting waste cooking oil with methanol that will produce methyl ester and glycerol with the aid of basic catalyst. The aims of this research to observe the influence of temperature and reaction time to produce biodiesel and to determine the value of first order kinetics parameters on biodiesel synthesis. This research was conducted using transesterification method with molar 1: 6 ratio with reaction time of 0.25, 0.5, 1, 2, 3, 6 and 10 min and the reaction temperature of $30,35,40,45,50$, and $55^{\circ} \mathrm{C}$. The materials used in this research include waste cooking oil, methanol and $\mathrm{NaOH}$. Parameters analyzed were yield, density, viscosity, reaction rate constant and activation energy. The reaction kinetics is constructed with the assumption that the transesterification reaction is a first order reaction and is a function of the temperature and non-biodiesel concentration. The results showed that the yield of biodiesel ranged from 0 to $78.44 \%$. The highest yield was at temperature of $55^{\circ} \mathrm{C}$ and reaction time of 10 minutes. The resulted biodiesel has a density between 0,863-0,885 gram/ $\mathrm{ml}$ and viscosity of 2,825-5,277 cSt meeting the SNI. The results showed that the higher the reaction temperature the greater the value of the reaction rate constant $(k)$. The $k$ values of $9.8\left(10^{-4}\right) \mathrm{s}^{-1}, 10,8\left(10^{-4}\right) \mathrm{s}^{-1}, 11.67\left(10^{-4}\right) \mathrm{s}^{-1}, 14,00\left(10^{-4}\right) \mathrm{s}^{-1}, 14.83\left(10^{-4}\right) \mathrm{s}^{-1}$, and $21.67\left(10^{-4}\right) \mathrm{s}^{-1}$ were respectively obtained for temperatures of $30,35.40,45.50$ and $55{ }^{\circ} \mathrm{C}$. The value of the activation energy (Ea) of the waste cooking oil transesterification reaction was $23.83 \mathrm{~kJ} / \mathrm{mol}$.
\end{abstract}

Keywords: Biodiesel, Waste cooking oil, Base Transesterification, Kinetics reaction

\begin{abstract}
ABSTRAK
Biodiesel merupakan alternatif pengganti bahan bakar solar yang dapat dibuat dari minyak jelantah. Pembuatan biodiesel dapat dilakukan dengan metode transesterifikasi yaitu mereaksikan antara minyak jelantah dan metanol sehingga menghasilkan metil ester dan gliserol dengan bantuan katalis basa. Penelitian ini bertujuan mengetahui pengaruh suhu dan waktu reaksi dalam pembuatan biodiesel dan menentukan nilai parameter kinetika orde satu pada sintesis biodiesel dari minyak jelantah untuk memprediksi hasil reaksi. Penelitian ini menggunakan rasio molar 1:6 dengan waktu reaksi sebesar 0.25, 0.5, 1, 2, 3, 6 dan 10 menit dan suhu reaksi sebesar 30, 35, 40, 45, 50 , dan $55^{\circ} \mathrm{C}$. Bahan yang digunakan meliputi minyak jelantah, metanol dan $\mathrm{NaOH}$ dengan parameter penelitian meliputi rendemen, massa jenis dan viskositas. Kinetika reaksi merupakan reaksi orde satu dari fungsi suhu dan konsentrasi non biodiesel untuk memperoleh konstanta laju reaksi dan energi aktivasi. Hasil penelitian menunjukkan rendemen biodiesel tertinggi terdapat pada suhu $55^{\circ} \mathrm{C}$ dan waktu reaksi 10 menit. Biodiesel yang dihasilkan memiliki massa jenis antara 0,863-0,885 gram/ml (sesuai SNI), dan viskositas 2,825-5,277 cSt (sesuai SNI). Nilai konstanta laju reaksi $(k)$ pada suhu suhu $30,35,40,45,50$ dan $55^{\circ} \mathrm{C}$ sebesar $9,8 \times 10^{-4} \mathrm{~s}^{-1}$, $10,8 \times 10^{-4} \mathrm{~s}^{-1}, 11,67 \times 10^{-4} \mathrm{~s}^{-1}, 14 \times 10^{-4} \mathrm{~s}^{-1}, 14,83 \times 10^{-4} \mathrm{~s}^{-1}$, dan $21,67 \times 10^{-4} \mathrm{~s}^{-1}$. Nilai energi aktivasi (Ea) reaksi yang dihasilkan sebesar $23,83 \mathrm{~kJ} / \mathrm{mol}$.
\end{abstract}

Kata Kunci: Biodiesel, Minyak Jelantah, Transesterifikasi Basa, Kinetika Reaksi 


\section{PENDAHULUAN}

Kebutuhan energi akan terus meningkat seiring bertambahnya jumlah penduduk dan kemajuan teknologi. Pada akhir 2014, cadangan minyak bumi Indonesia tersisa 10,5 miliar ton dan hanya akan bertahan selama 12 tahun apabila dihitung dengan tingkat produksi 852 ribu barrel per hari (British Petroleum, 2015). Cadangan semakin menipis karena produksi bahan bakar minyak bumi di Indonesia mengalami penurunan 10\% sedangkan tingkat konsumsinya naik sekitar 6\% setiap tahunnya (Bambang, 2006). Energi alternatif diperlukan sebagai salah satu solusi mengurangi ketergantungan pada minyak bumi yang salah satunya adalah biodiesel.

Biodiesel merupakan salah satu energi alternatif pengganti bahan bakar diesel atau solar yang dapat diperbaharui. Terdapat lebih dari 50 jenis bahan baku yang berpotensi sebagai bahan utama membuat biodiesel di Indonesia yaitu minyak jelantah, kelapa sawit, kelapa, alga, jarak pagar dan karet (Kucahyo dkk., 2013). Minyak jelantah merupakan salah satu bahan yang potensial untuk digunakan karena mudah ditemui di masyarakat, tersedia secara kontinu dan harganya terjangkau bahkan gratis. Selain itu, minyak jelantah merupakan limbah rumah tangga yang memiliki kandungan karsinogenik cukup tinggi sehingga pemanfaatan limbah minyak jelantah juga dapat mengatasi masalah pencemaran lingkungan dan kesehatan masyarakat.

Proses pembuatan biodiesel dari minyak jelantah dapat menggunakan metode transesterifikasi. Metode transesterifikasi yaitu metode yang mereaksikan minyak jelantah dengan alkohol dan katalis yang akan menghasilkan biodiesel dan gliserol. Transesterifikasi dapat dilakukan dengan katalis asam untuk minyak yang memiliki kandungan FFA tinggi. Reaksi ini akan berlangsung lambat dan diperlukan rasio molar alkohol:minyak yang tinggi (bisa lebih dari 30:1). Canakci dan van Gerpen (1999) mempelajari produksi biodiesel menggunakan katalis asam sulfat Konversi ester dilaporkan meningkat dari 87,8\% menjadi 95,1\% ketika waktu reaksi dinaikkan dari 48 jam hingga 96 jam. Dalam studi lainnya, Crabbe et al. (2001) menemukan bahwa transesterifikasi menggunakan $5 \% \mathrm{H}_{2} \mathrm{SO} 4$, pada $95^{\circ} \mathrm{C}$ mencapai konversi ester hingga 99,7\% pada rasio molar alkohol:minyak pada 40:1 dan lama reaksi 9 jam. Transesterifikasi menggunakan katalis basa adalah yang paling banyak digunakan karena hanya memerlukan rasio molar alkohol:minyak 6:1 dan sedikit katalis ( $\mathrm{NaOH}$ atau $\mathrm{KOH})$. Kelemahan reaksi ini adalah adanya reaksi sampingan berupa safonifikasi (penyabunan) yang akan memakan katalis sehingga dapat menurunkan produksi biodiesel, khususnya jika kandungan FFA dalam minyak nabati cukup tinggi.

Faktor yang mempengaruhi hasil reaksi yaitu suhu dan waktu reaksi. Analisis kinetika reaksi diperlukan untuk memprediksi hasil reaksi pada suhu dan waktu tertentu yang paling optimal. Kinetika reaksi yang digunakan adalah kinetika reaksi orde satu untuk memperoleh laju reaksi $(k)$ dan energi aktivasi $(E a)$. Berdasarkan hal tersebut, penelitian ini bertujuan mengetahui pengaruh suhu dan waktu reaksi dalam pembuatan biodiesel dan menentukan nilai parameter kinetika orde satu pada sintesis biodiesel dari minyak jelantah untuk memprediksi hasil reaksi.

\section{BAHAN DAN METODE}

Penelitian ini dilakukan pada 5 Oktober-5 November 2017 di Laboratorium Rekayasa Sumber Daya Air dan Lahan, Jurusan Teknik Pertanian Fakultas Pertanian, Universitas Lampung, Bandar Lampung. Alat digunakan pada penelitian ini adalah pipet tetes, stirer, heater, alumunium foil, labu erlenmeyer, gelas ukur, gelas beaker, botol bening, timbangan analitik, falling ball viscometer, ruber bulb, termometer, piknometer, spatula, stopwatch, sarung tangan, dan masker. Bahan yang digunakan adalah minyak jelantah, metanol teknis, $\mathrm{NaOH}$, dan aquades.

Penelitian ini menggunakan metode transesterifikasi dengan perbandingan rasio molar 1:6. Faktor waktu reaksi menggunakan 7 taraf perlakuan dan faktor suhu reaksi menggunakan 6 taraf perlakuan. Waktu reaksi terdiri dari $0.25,0.5,1,2,3,6$ dan 10 menit sedangkan suhu reaksi terdiri dari 30, 35, 40, 45, 
50, dan $55^{\circ} \mathrm{C}$. Parameter pada penelitian ini adalah rendemen dan analisis kinetika.

\subsection{Perhitungan Rendemen}

Rendemen biodiesel diperlukan untuk menyusun persamaan kinetika reaksi. Rendemen biodiesel (\%) dihitung dari Persamaan (1):

Rendemen $=\frac{\text { Bobot Biodiesl }}{\text { Bobot Minyak Jelantah }} \times 100 \%$

\subsection{Analisis Kinetika}

Kinetika reaksi dapat dirunut dengan Persamaan 2 - Persamaan 6.

Laju reaksi $=$ Rate $=-\frac{d[N B D]}{d t}=k[N B D]$

dimana $N B D$ adalah fraksi non-biodiesel, [NBD] konsentrasi non biodiesl, $t$ waktu reaksi, dan $k$ konstanta laju rekasi. Persamaan (2) dapat dirangkai ulang sebagai:

$$
-\frac{\mathrm{d}[\mathrm{NBD}]}{[\mathrm{NBD}]}=\mathrm{kdt}
$$

Pada $t=0$ konsentrasi $N B D$ adalah $\left[N B D_{0}\right]$ dan pada $t=t$ konsentrasi $N B D$ adalah $\left[N B D_{\mathrm{t}}\right]$, dimana $\left[N B D_{0}\right]>\left[N B D_{\mathrm{t}}\right]$. Integrasi Pers. (3) menghasilkan:

$$
-\int_{N B D_{t}}^{\mathrm{NBD}_{0}} \frac{\mathrm{d}[\mathrm{NBD}]}{[\mathrm{NBD}]}=\mathrm{k} \int_{0}^{\mathrm{t}} \mathrm{dt}
$$

Atau

$$
-\ln \frac{\left[\mathrm{NBD}_{\mathrm{t}}\right]}{\left[\mathrm{NBD}_{0}\right]}=\mathrm{kt}
$$

Dengan asumsi bahwa pada $t=0$, belum ada biodiesel dan semua komponen dianggap $N B D$ maka :

$$
\frac{\left[\mathrm{NBD}_{\mathrm{t}}\right]}{\left[\mathrm{NBD}_{0}\right]}=\frac{\left[\mathrm{NBD}_{0}\right]-\left[\mathrm{BD}_{\mathrm{t}}\right]}{\left[\mathrm{NBD}_{0}\right]}=1-\frac{\left[\mathrm{BD}_{\mathrm{t}}\right]}{\left[\mathrm{NBD}_{0}\right]}
$$

Seperti diberikan dalam Persamaan (1) $\left[N B D_{\mathrm{t}}\right] /$ $\left[N B D_{0}\right]$ adalah rendemen biodiesel. Dengan mensubstitusikan rendemen biodiesel, maka Persamaan (7) dapat disajikan sebagai:

$$
1-\text { Rendemen }=\exp (-k t)
$$

Nilai $k$ yaitu konstanta laju reaksi diperoleh dari plot eksponensial (1 - Rendemen) versus $t$ pada suhu yang berbeda-beda. Selanjutnya nilai-nilai konstanta laju reaksi digunakan untuk menentukan nilai energi aktivasi global $(E a)$. Nilai $E a$ diperoleh dari plot eksponensial $k$ versus $1 / T$ dari reaksi transesterifikasi dengan menggunakan Persamaan Arrhenius :

$$
k=A \exp (-E a / R T)
$$

$\operatorname{dimana} A$ adalah konstanta frekuensi tumbukan molekul, $R$ konstanta gas universal $(8,3145 \mathrm{~J} /$ mol.K), dan $T$ suhu mutlak (K).

\subsection{Pengujian Model Kinetika}

Pengujian model persamaan dilakukan untuk membandingkan rendemen yang dihasilkan pada observasi dengan rendemen yang diprediksi. Validasi model persamaan ini dilakukan untuk mengetahui keakuratan model kinetika yang telah dibuat. Validasi model dilakukan dengan data rendemen biodiesel pada waktu reaksi 8 menit pada tiap suhu. Keakuratan hasil validasi diketahui dari persentase data yang berada di wilayah $B D_{t} \pm$ RMSE pada grafik.

\section{HASIL DAN PEMBAHASAN}

\subsection{Rendemen Biodiesel}

Rendemen merupakan jumlah biodiesel yang dihasilkan dari minyak jelantah sampai menjadi biodiesel dalam satuan persen (\%). Rendemen Biodiesel yang dihasilkan disajikan pada Tabel 1 dan Gambar 1.

Gambar 1 menunjukkan bahwa rendemen tertinggi terjadi pada kondisi suhu $55^{\circ} \mathrm{C}$ dengan waktu reaksi 10 menit yaitu sebesar 78,44\%. Penelitian sebelumnya dengan cara konvensional dilaporkan oleh Sinaga (2014) bahwa rendemen tertinggi yang dihasilkan sebesar $72,87 \%$ dengan suhu $65^{\circ} \mathrm{C}$ pada waktu 30 menit. Penelitian sebelumnya melaporkan rendemen yang dihasikan menggunakan gelombang ultrasonik frekuensi $42 \mathrm{kHz}$ memerlukan waktu 30 menit untuk menghasilkan 70,67\% (Desiyana, 2014) dengan rasio molar 1:6, dan perbandingan molar 1:4 menghasikan rendemen sebesar 76,6 \% (Yozana, 2016). Hal ini menunjukkan bahwa 
Tabel 1. Rendemen biodiesel sebagai fungsi waktu dan suhu reaksi

\begin{tabular}{ccccccc}
\hline \multirow{2}{*}{$\begin{array}{c}\text { Waktu } \\
\text { (menit) }\end{array}$} & $30{ }^{\circ} \mathrm{C}$ & $35{ }^{\circ} \mathrm{C}$ & $40{ }^{\circ} \mathrm{C}$ & $45{ }^{\circ} \mathrm{C}$ & $50{ }^{\circ} \mathrm{C}$ & $55^{\circ} \mathrm{C}$ \\
\cline { 2 - 7 } & 0 & 0 & 0 & 0 & 0 & 0 \\
0 & 38,88 & 35,44 & 33,64 & 24,62 & 30,08 & 22,57 \\
0,25 & 41,82 & 42,72 & 40,63 & 34,01 & 42,80 & 29,02 \\
1 & 43,69 & 48,50 & 44,54 & 41,50 & 49,69 & 33,07 \\
2 & 47,86 & 51,49 & 48,52 & 49,47 & 51,87 & 38,64 \\
3 & 52,59 & 56,24 & 54,43 & 56,91 & 58,34 & 54,69 \\
6 & 58,46 & 64,02 & 62,90 & 61,11 & 62,62 & 67,56 \\
10 & 66,19 & 67,67 & 67,61 & 69,92 & 75,46 & 78,44 \\
\hline
\end{tabular}
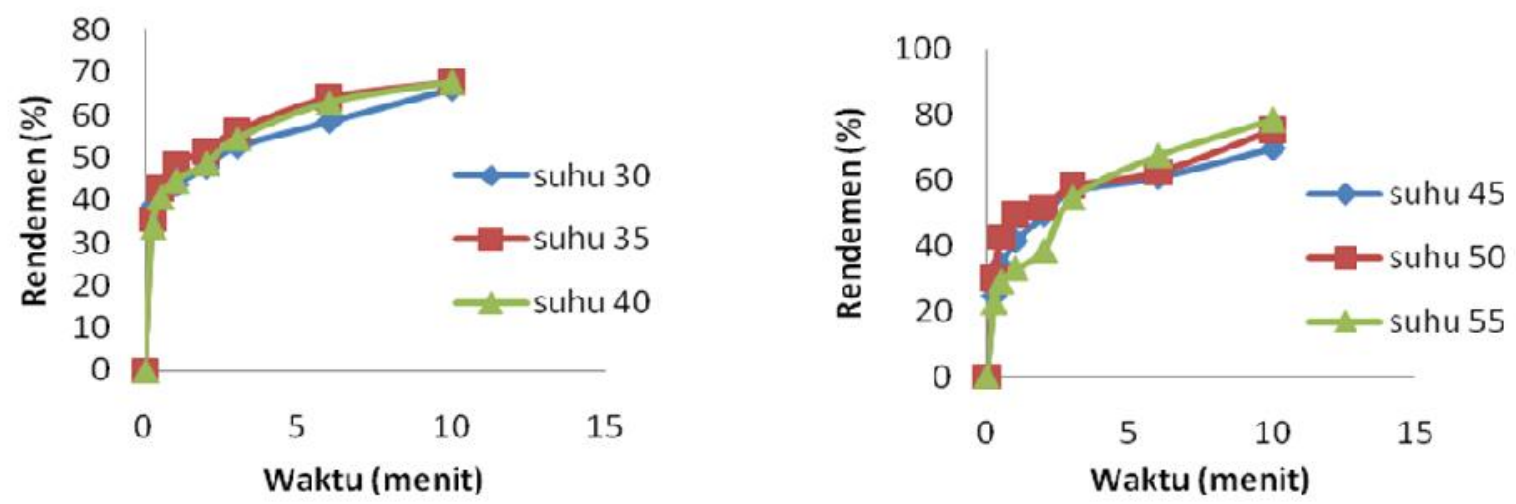

Gambar 1. Rendemen biodiesel sebagai fungsi waktu dan suhu reaksi

perbandingan molar 1:6, suhu yang tinggi dan waktu reaksi yang lama menghasilkan rendemen yang lebih besar.

\subsection{Kinetika Reaksi Biodiesel}

\subsubsection{Konstanta Laju Reaksi $(k)$}

Kinetika reaksi mempelajari laju berlangsungnya reaksi dan energi yang terlibat dalam proses tersebut serta mekanisme berlangsungnya reaksi. Tabel 2 menunjukkan hasil perhitungan $\left.N B D_{\mathrm{t}}\right] /\left[N B D_{0}\right]$ pada berbagai suhu dan waktu reaksi. Konstanta laju reaksi $(k)$ diperoleh dari plot $\left[N B D_{\mathrm{t}}\right] /\left[N B D_{0}\right]$ versus waktu reaksi seperti disajikan pada Gambar 2.
Gambar 2 menghasilkan persamaan $y=C \exp (-k$ $x$ ). Setiap suhu memiliki nilai konstanta laju reaksi yang berbeda-beda. Kecenderungan adalah bahwa konstanta laju reaksi transesterifikasi minyak jelantah meningkat terhadap suhu seperti yang disajikan pada Tabel 3. Nilai $k$ berbanding lurus dengan peningkatan suhu, artinya semakin tinggi suhu maka nilai $k$ akan semakin besar hal ini disebabkan karena semakin tinggi suhu, laju pergerakan setiap molekul akan semakin cepat, sehingga reaksi akan semakin cepat (Yozana, 2016).

Tabel 2. Data $\left[N B D_{\mathrm{t}}\right] /\left[N B D_{0}\right]$ pada berbagai suhu dan waktu reaksi

\begin{tabular}{ccccccc}
\hline \multirow{2}{*}{$\begin{array}{c}\text { Waktu Reaksi } \\
\text { (menit) }\end{array}$} & $30^{\circ} \mathrm{C}$ & $35^{\circ} \mathrm{C}$ & $40{ }^{\circ} \mathrm{C}$ & $45^{\circ} \mathrm{C}$ & $50{ }^{\circ} \mathrm{C}$ & $55^{\circ} \mathrm{C}$ \\
\hline 0,25 & 0,61 & 0,65 & 0,66 & 0,75 & 0,70 & 0,77 \\
0,5 & 0,58 & 0,57 & 0,59 & 0,66 & 0,57 & 0,71 \\
1 & 0,56 & 0,51 & 0,55 & 0,59 & 0,50 & 0,67 \\
2 & 0,52 & 0,49 & 0,51 & 0,51 & 0,48 & 0,61 \\
3 & 0,47 & 0,44 & 0,46 & 0,43 & 0,42 & 0,45 \\
6 & 0,42 & 0,36 & 0,37 & 0,39 & 0,37 & 0,32 \\
10 & 0,34 & 0,32 & 0,32 & 0,30 & 0,25 & 0,22 \\
\hline
\end{tabular}



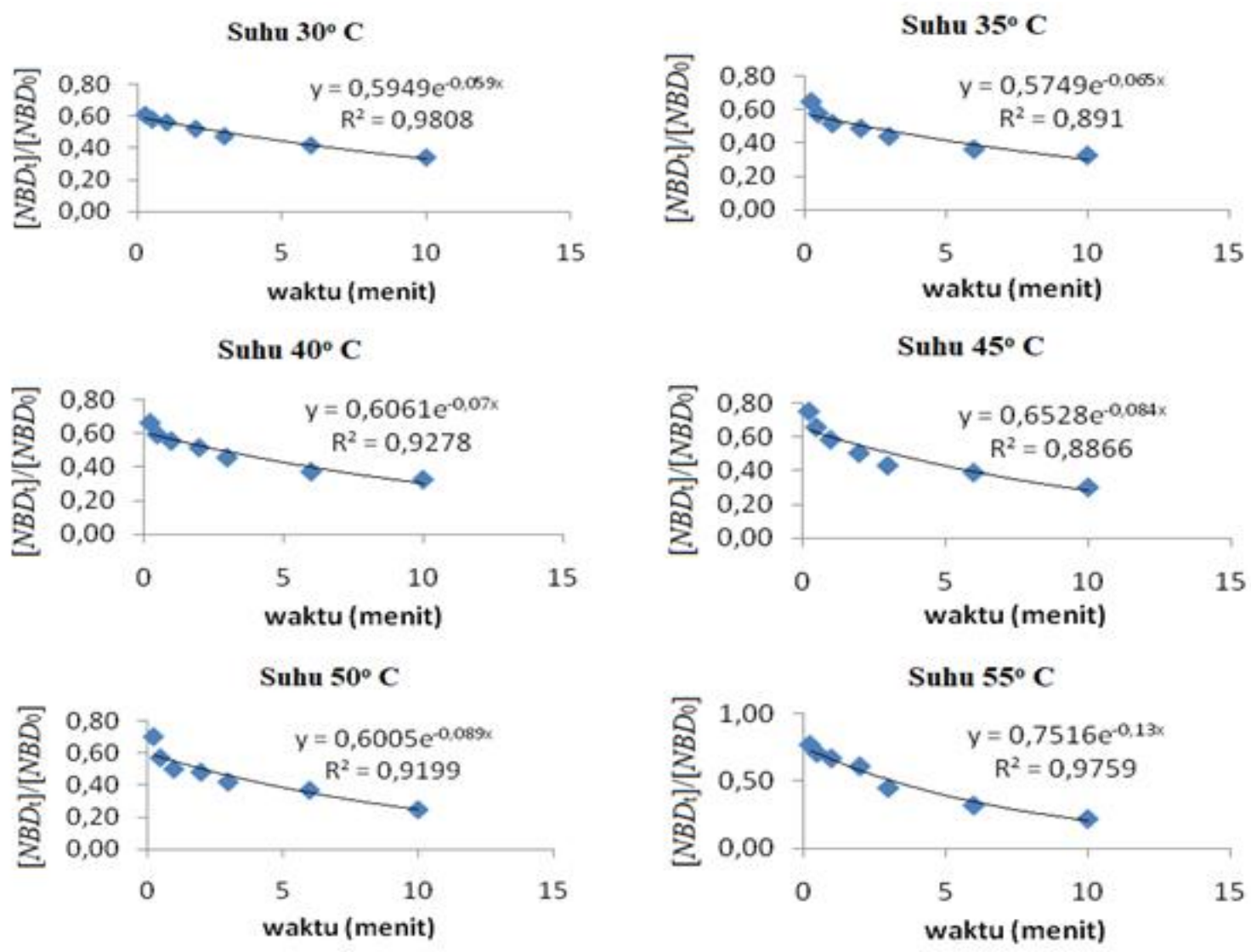

Gambar 2. Hubungan antara $\left[N B D_{\mathrm{t}}\right] /\left[N B D_{0}\right]$ dengan waktu reaksi pada berbagai suhu

Tabel 3. Hubungan suhu dengan konstanta laju reaksi pada berbagai suhu

\begin{tabular}{cc}
\hline Suhu $\left({ }^{\circ} \mathrm{C}\right)$ & $k$ per menit \\
\hline 30 & 0,059 \\
35 & 0,065 \\
40 & 0,070 \\
45 & 0,084 \\
50 & 0,089 \\
55 & 0,130 \\
\hline
\end{tabular}

Penelitian sintesis biodiesel menghasilkan nilai konstanta laju reaksi terbesar yaitu 0,130 per menit pada suhu $55^{\circ} \mathrm{C}$ dan nilai konstanta laju reaksi pada suhu $55^{\circ} \mathrm{C}$ ini lebih besar, jika dibandingkan dengan konstanta laju reaksi yang dihasilkan pada penelitian Renata (2016). Dengan menggunakan bahan baku minyak jelantah dan bantuan gelombang mikro, Renata (2016) mendapatkan nilai konstanta 0,096 pada suhu $55^{\circ} \mathrm{C}$ dengan perbandingan molar $1: 4$. Hal ini menunjukkan bahwa rasio molar yang digunakan berpengaruh terhadap laju reaksi.

\subsubsection{Energi Aktivasi (Ea)}

Data hubungan konversi biodiesel sebagai fungsi suhu dan waktu dapat digunakan sebagai data untuk menentukan harga setiap parameter pada model kinetika yang diusulkan. Berdasarkan Persamaan (8), maka dapat dibuat plot eksponensial hubungan antara nilai $k$ terhadap invers suhu $(1 / T)$ seperti disajikan pada Gambar 3. Sebagaimana terlihat pada gambar, hubungan tersebut menghasilkan Persamaan (9):

$$
y=708,12 \exp (-2866 x)
$$

Nilai $(E a / R)$ pada Persamaan (9) sebesar -2866 sehingga dengan nilai $R$ sebesar 8,314 maka nilai Ea adalah 23,83 kJ/mol. Persamaan (9) juga menunjukkan bahwa nilai konstanta frekuensi tumbukan sebesar 708,12 per menit. Energi aktivasi ditentukan dari konstanta laju eksperimental atau koefesien yang diukur pada temperatur yang berbeda yang berarti ketergantungan pada suhu laju reaksi (Renata, 2016). Energi aktivasi sendiri dapat 


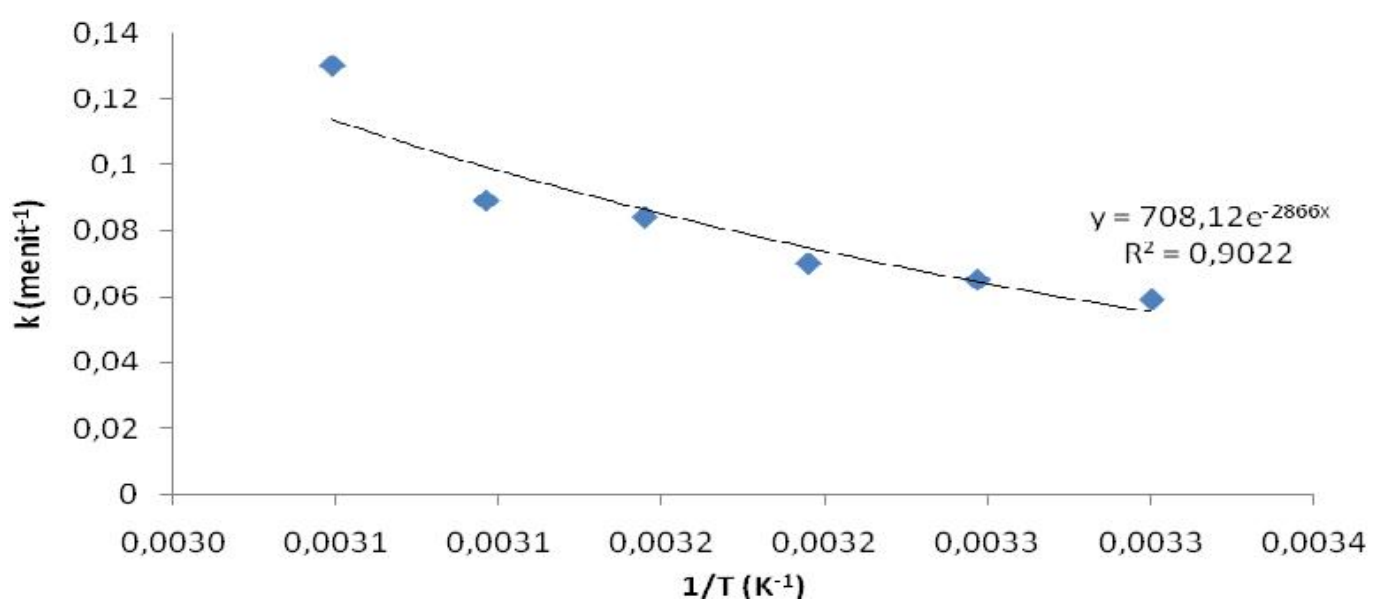

Gambar 3. Hubungan antara $1 / T$ dengan nilai $k$

didefinisikan sebagai energi yang harus dilampaui agar reaksi kimia dapat terjadi. Energi aktivasi dapat menunjukkan tingkat kemudahan atau kesulitan reaksi tersebut berlangsung, yang secara teori jika suatu reaksi memiliki energi aktivasi yang lebih kecil akan cenderung bereaksi lebih cepat dan mudah dibandingkan dengan suatu reaksi yang memiliki energi aktivasi lebih besar yang cenderung akan bereaksi lebih sulit dan lama (Rahman dan Sanjaya, 2012). Semakin besar nilai konstanta laju reaksi, maka reaksi akan berlangsung cepat. Semakin cepat suatu reaksi memungkinkan terjadinya tumbukan partikel dalam jumlah besar dengan waktu yang relatif singkat dan tingkat energi yang lebih rendah sehingga keseimbangan akan tercapai pada waktu yang lebih cepat.

Tabel 5. Perbandingan Rendemen Biodiesel Hasil Penelitian dan Perhitungan

\begin{tabular}{ccccc}
\hline $\begin{array}{c}\text { Suhu } \\
\left({ }^{\circ} \mathrm{C}\right)\end{array}$ & $\begin{array}{c}\text { Rendemen (\%) } \\
\text { Observasi }\end{array}$ & $\begin{array}{c}\text { Rendemen }(\%) \\
\text { Prediksi }\end{array}$ & Error & Kuadrat Error \\
\hline 30 & 63 & 62 & 1,5 & 2,3 \\
35 & 66 & 66 & 0,1 & 0,0 \\
40 & 66 & 67 & $-1,0$ & 1,0 \\
45 & 68 & 67 & 0,7 & 0,5 \\
50 & 72 & 73 & $-1,3$ & 1,6 \\
55 & 75 & 70 & 5,8 & 33,5 \\
\hline & & MSE & 6,5 \\
& & & RMSE & 2,5 \\
\hline
\end{tabular}

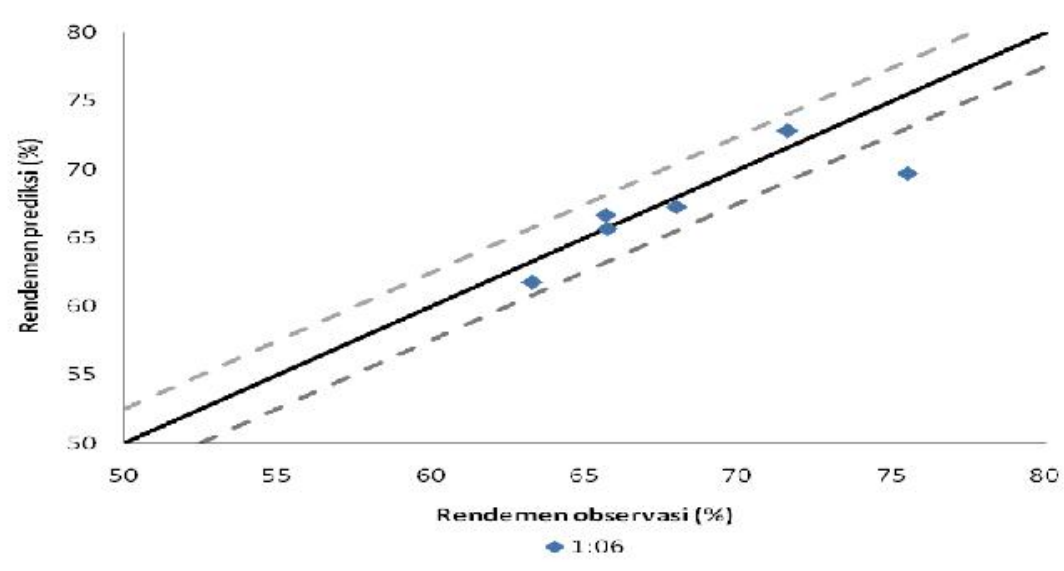

Gambar 4. Hubungan antara Rendemen Observasi dengan Rendemen Prediksi 


\subsection{Pengujian Model Kinetika}

Validasi model kinetika dilakukan untuk membandingkan rendemen hasil observasi dengan rendemen hasil prediksi. Rendemen hasil observasi dan rendemen hasil prediksi pada rasio molar 1:6 disajikan pada Tabel 5. Validasi model kinetika dilakukan untuk mengetahui keakuratan model yang dibuat. Hubungan antara rendemen hasil observasi dan rendemen prediksi ditunjukkan pada Gambar 4.

Gambar 4 menunjukkan akurasi prediksi rendemen terhadap rendemen hasil observasi. Nilai rendemen prediksi berada dalam batas RMSE namun ada satu data yang berada di luar batas RMSE. RMSE merupakan akar kuadrat dari rata-rata jumlah kuadrat error tiap data yang dalam penelitian ini sebesar $\pm 2,5 \%$. Dari 6 sampel, satu sampel pengujian berada di luar batas RMSE yaitu pada suhu $55{ }^{\circ} \mathrm{C}$. Dapat disimpulkan bahwa tingkat akurasi model persamaan yang dihasilkan dalam penelitian ini sebesar $83,33 \%$, sehingga model persamaan memiliki tingkat keakuratan yang baik (di atas 80\%).

\section{KESIMPULAN}

Berdasarkan penelitian yang telah dilakukan, beberapa kesimpulan yang dapat ditarik adalah:

1. Rendemen biodiesel tertinggi dihasilkan pada kondisi suhu $55^{\circ} \mathrm{C}$ dengan waktu reaksi 10 menit yaitu sebesar $78,44 \%$

2. Biodiesel yang dihasilkan memiliki massa jenis berkisar antara $0,863-0,885 \mathrm{~g} / \mathrm{ml}$ (memenuhi SNI 0,85-0,89 g/ml), viskositas biodiesel berkisar antara 2,825-5,277 cSt (memenuhi SNI 2,3-6,0 cSt).

3. Hasil penelitian menunjukkan bahwa semakin tinggi suhu rekasi maka semakin besar nilai konstanta laju reaksi $(k)$. Nilai $k$ yang diperoleh adalah $9,8\left(10^{-4}\right) \mathrm{s}^{-1}, 10,8\left(10^{-}\right.$ $\left.{ }^{4}\right) \mathrm{s}^{-1}, 11,67\left(10^{-4}\right) \mathrm{s}^{-1}, 14,00\left(10^{-4}\right) \mathrm{s}^{-1}, 14,83$ $\left(10^{-4}\right) \mathrm{s}^{-1}$, dan $21,67\left(10^{-4}\right) \mathrm{s}^{-1}$ berturut-turut diperoleh untuk suhu 30, 35,40,45,50 dan 55 ${ }^{\circ} \mathrm{C}$.

4. Nilai energi aktivasi (Ea) reaksi transesterifikasi minyak jelantah yang dihasilkan sebesar 23,83 kJ/mol.
5. Model persamaan yang dihasilkan pada penelitian ini memiliki nilai RMSE sebesar \pm $2,5 \%$ dan tingkat keakuratan sebesar $83,33 \%$.

\section{ACKNOWLEDGEMENT}

Penelitian ini didanai oleh Direktorat Riset dan Pengabdian Masyarakat, Direktorat Jenderal Penguatan Riset dan Pengembangan, Kementerian Riset, Teknologi dan Pendidikan Tinggi melalui skim Riset Fundamental dengan nomor kontrak: 071/SP2H/LT/DRPM/IV/ 2017585.

\section{DAFTAR PUSTAKA}

Bambang. 2006. Biodiesel Sumber Energi Alternatif Pengganti Solaryang Terbuat dari Ekstraksi Minyak Jarak Pagar. Trubus Agrisarana. Surabaya.

British Petroleum. 2015. BP Statistical Reviewof World Energy June 2015. (diakses dari https://www.bp.com tanggal 2 Agustus 2017).

Canakci, M. dan Gerpen, J.V. 1999. Biodiesel production via acid catalysis. Transactions of the ASAE Vol. 42(5): 1203-1210.

Crabbe, E., Nolasco-Hipolito, C., Kobayashi, G., Sonomoto, K., dan Ishizaki, A. 2001. Biodiesel production from crude palm oil dan evaluation of butanol extraction dan fuel properties. Process Biochemistry. Vol. 37: 65-71.

Desiyana, V. 2014. Pengaruh Rasio Molar dan Waktu Reaksi Terhadap Hasil dan Mutu Biodiesel dari Minyak Jelantah Melalui Transesterifikasi yang Dibantu Gelombang Ultrasonik. Skripsi. Universitas Lampung. Bandar Lampung. $105 \mathrm{hlm}$.

Kuncahyo, P., Fathallah, A.Z.M., dan Semin. 2013. Analisa prediksi potensi bahan baku biodiesel sebagai suplemen bahan bakar motor diesel di Indonesia. Jurnal Teknik Pomits. Vol. 2(1): 2301 - 9271. 
Rahman, A.Z. dan Sanjaya, I.G.M. 2012. Rasionalisasi jalur sintesis laevifonal dari trans-resveratol dengan menggunakan teori fungsional kerapatan (DFT). UNESA Journal of Chemistry.Vol. 1(1) : 1-9.

Renata, M.O., 2016. Kinetika Reaksi Transesterifikasi Minyak Jelantah dengan Bantuan Gelombang Mikro. Skripsi. Universitas Lampung. Bandar Lampung. 36 hlm.
Sinaga S. V, Haryanto, A., Triyono, S. 2014. Pengaruh suhu dan waktu reaksi pada proses pembuatan biodiesel dari minyak jelantah. Jurnal Teknik Pertanian Lampung, vol. 3(1):27-34).

Yozana, 0. 2016. Kinetika Transesterifikasi Minyak Jelantah. Skripsi. Universitas Lampung. Bandar Lampung. $37 \mathrm{hlm}$. 